\title{
A Study on Child Labour in Assam with Special Reference to Dibrugarh Town
}

\author{
Sangeeta Khanikor \\ Research Scholar Department of Education Dibrugarh University
}

\begin{abstract}
Background-As is the case with other developing countries of the world, child labour is also a problem in India. Though child labour in the country has been banned by the Supreme Court, the order of the apex court is yet to be implemented in true spirit. It has become a common sight to see a child working in a garage, hotel, and business establishment and under hazardous condition as well throughout the country. Assam is also not an exception in this regard. The present study was done to understand the causes and consequences of child work prevalent in the consciousness of the work force involved in child development and to suggest ways and means to divert erroneous and deeply engraved notions on sociological perspective.

Objectives- To assess the reasons for the exploitation of child labour the nature and magnitude of problems encountered by child labours.

Method-Both qualitative and quantitative methods were employed in this study.

Findings- A total of 60 child labours participated in the survey. About $40 \%$ of children were below the age of 14 years and were engaged in employed labour. None of the child labours interviewed was at school during the study period. The reason for child labour included poverty (33.3\%), loss of parents (16.6\%), parental separation (27\%) and shortage of food (23.3\%). Among the respondent $28.3 \%$ were domestic child labours, $20 \%$ were street child labours and 35\% were working in private organizations. Two third of the child labours were working for more than 10 hours a day and their daily income of less than 150 Rs. Most of them did not visit their parents or relatives for long period of time.

Conclusion- The study indicated that child labourers are denied the liberating benefit of education, their health, growth and development are threatened and that they have lost the love and affection, care and protection of their families and could not enjoy the rest and recreation that are rights of every child.
\end{abstract}

\section{Introduction}

Child labour remains to be a serious problem in the world today. According to the International Labour Organization (ILO), millions of children in the world work in hazardous and intolerable occupations. Currently the numbers of working children in the world are between the ages of 5 and 14 about 200 millions.

According to the national child labour survey report of 2001, children are engaged in productive and non productive works beyond their capacity in both the urban and rural areas in India. In the urban areas, children are often forced into labour due to situations of persisting poverty which requires all family members to contribute to the household income. Many factors are known to have contributed to the health problems of child labourers. This could be due to the fact that most of labourers perform tasks that are beyond their capacity or punishment by employers or other people.

This study was conducted to assess the situation and problems of child labour in Assam. More specifically, the objectives of the study were to describe the socio-economic, personal and demographic situations of child labour; describe the magnitude and severity of the problems, identify and analyze factors that contribute to child labour, and recommend possible strategies for interventions that can alleviate the problems of child labourers.

\section{Methodology}

Study area and population- the study was conducted in Dibrugarh town in Assam. The town area was selected because here with a rapidly increasing number of child labourers.

Study design- both qualitative and quantitative methods were applied in the study. Qualitative data was collected by using interview and by carrying out observations. Quantitative data was collected by using a multistage sampling method to identify or select the study participant (respondent).

Instruments used for data collection- well structured interview scheduled were used to collect the data. 


\section{Results}

Demographic characteristics of respondent- A total of 60 child labourers from dibrugarh town area participated in the survey. Children in the age range of 5-18 years were used for the study. More than half of the respondents were in the age group of 14-18 years. About $40 \%$ of them in the youngest age group (5-9 years old).

Of all the respondents who participated in the survey, $30 \%$ were illiterate, $20 \%$ could read and write, $23.3 \%$ were withed primary school education and $26.6 \%$ were secondary school education.

The predominant religion in the study population was Hindu that comprised of $43.3 \%$, Christian were $18.3 \%$ and $38.3 \%$ were Muslim religion.

Table no-1Socio-demographic characteristics of child labourers in Dibrugarh town

\begin{tabular}{|l|l|l|}
\hline \multicolumn{2}{|l|}{ characteristics } & \multicolumn{2}{l}{ Child labourer $(\mathbf{N}=\mathbf{6 0})$} \\
frequency & percentage \\
\hline Age & 2 & 3.3 \\
$5-9$ & 24 & 40 \\
$10-13$ & 34 & 56 \\
$14-18$ & & \\
\hline Sex & 42 & 70 \\
Male & 18 & 30 \\
Female & & \\
\hline Educational level & 18 & 30 \\
Illiterate & 12 & 20 \\
Read and Write & 14 & 23.3 \\
Primary & 16 & 26.6 \\
Secondary & & \\
\hline Religion & 26 & 43.3 \\
Hindu & 11 & 18.3 \\
Christian & 23 & 38.3 \\
Muslim & & \\
\hline
\end{tabular}

The working conditions of child labourers- Among 60 child labourers $28.3 \%$ mentioned that they were working in the home of individuals ( as domestic labourers). Furthermore,20\% of them reported that they were street labourers and they were employed to sell small items on the streets, carrying household goods or items near or around market places and carrying passengers bags and others goods around bus stations. 35\% worked in private organizations like hotels, restaurants, shops garages etc and $16.6 \%$ performed different labour within the town as and when they get the chance.

About 35\% of the respondent working in private organizations mentioned that they served as waiters providing coffee, tea or meal service in the hotels, restaurants and bars. Some were provided cleaning services in the hotels.

The overwhelming majority of the child labourers reported that they got payment for the work they performed. About $61.6 \%$ of the respondent mentioned that their daily income is less than $150.35 \%$ of them had a daily income of between 150-190 Rs and only 3.3\% earned more than 200 (210 if over timed). Concerning average daily working hours, the majority of the respondents worked for more than 10 hours per day, while $38.3 \%$ worked for 8-10 hours. Half of the respondents have stayed in the job for more than one year

Table No 2 The working conditions of child labourers $(\mathrm{N}=60)$

\begin{tabular}{|l|l|l|}
\hline \multicolumn{2}{|l|}{} & \multicolumn{2}{l|}{ Respondent (N=60) } \\
Variables & $\begin{array}{l}\text { Frequency } \\
\text { Percentage }\end{array}$ \\
\hline Reasons for being child labour & 20 & 33.3 \\
Poverty & 10 & 16.6 \\
Parental loss & 16 & 26.6 \\
Parental separation & 14 & 23.3 \\
Shortage of food & & \\
\hline Types of work & 17 & 28.3 \\
Domestic work & 12 & 20 \\
Working on street & 21 & 35 \\
In private organization & 10 & 16.6 \\
Working any labour work & & \\
\hline Daily working hours & 23 & 38.3 \\
8-10 & 37 & 61.6 \\
More than 10 & 37 & 61.6 \\
\hline Amount of daily income & 21 & 35 \\
Less than 150 & 2 & 3.3 \\
150-190 & 28 & 46.6 \\
More than 200 & 32 & 53.3 \\
\hline Duration stayed in the work & \multicolumn{2}{|l}{} \\
Less than one year & 1-2 years & \\
\hline
\end{tabular}




\section{Reasons for being child labourer and family condition-}

Concerning the reasons for child labour, $33.3 \%$ of them reported that they came to this place in search of work, $16.6 \%$ due to loss of parents, $26.6 \%$ due to parental separation and $23.3 \%$ due to shortage of food. The result shows that $43.3 \%$ of the child labours were from broken families (one or more of their parents were not alive or have separated).

Health problem

Majority of the respondent reported that they faced many health problems. Malaria like illness and respiratory diseases are the major health problem reported by $83 \%$ of the respondent, eye problem $11.4 \%$ and $6.6 \%$ were faced skin problem.

According to the respondent malaria like illnesses had sign symptoms such as headache, fever sweating etc. The respiratory diseases are characterized by chest pain, cough, fever etc. Among child labourers who reported health problems, $63.26 \%$ attended government facilities, $20.4 \%$ attended private health institutions, $10.2 \%$ used traditional medicines and $6.12 \%$ did not seek any medical treatment.

Table No-3

Percentage distribution of health problems encountered, sources of health care reported by respondent

\begin{tabular}{|l|l|l|}
\hline \multicolumn{2}{|l|}{ Respondent } \\
Characteristics & \multicolumn{2}{|l|}{ Frequency Percentage } \\
\hline Faced health problems (N=60) & 49 & 81.6 \\
Yes & 11 & 18.3 \\
No & 22 & \\
\hline Diseases encountered (N=49) & 18 & 44.8 \\
Malaria like illness & 3 & 36.7 \\
Respiratory tract diseases & 6 & 6.1 \\
Skin disease & 31 & 12.2 \\
Eye problem & 10 & 63.26 \\
\hline Sources of health care $(\mathrm{N}=49)$ & 5 & 20.4 \\
Government health facilities & 3 & 10.2 \\
Private health facilities & 6.12 \\
Traditional medicine & \\
Did not go anywhere & \\
\end{tabular}

Knowledge of Child Right Convention (CRC)- a majority of child labourers had never heard of Child Right Convention and not aware of children's rights.

Major Problems

On the above analysis results indicated that the child labourers had the following major problems

- Because they are helpless some individual pay less amount of money or not at all for the worked they performed.

- Because of their living condition, they are exposed to physical abuse, (they are beaten by their employers)

- Due to heavy work load, poor working conditions, malnutrition, exposure to harsh environmental conditions (working during very cold and hot weather) and poor sanitation they become vulnerable to diseases.

- Because of long hours of work, denial of permission from their employers and financial problems, they are not able to get the opportunity for education.

\section{Discussion}

Though child labour in the country has been banned by the Supreme Court, the order of the apex court is yet to be implemented in true spirit. It has become a common sight to see a child working in a garage, hotel and business establishment, and under hazardous conditions as well throughout the country. Assam is also not an exception in this regard.Several thousands of child labourers working in garages, hotels, etc. A certain percentage of domestic workers in the city are of 14 years of age or younger.

Though poverty is the main cause which forces many children belonging to the poor families in the city to work as child labourers, the State government has so far failed to rescue many of these child labourers. Sources in the Labour Commissioner office said that only 45 child labourers were rescued in the city from January 2012 to September 2012. At least 27 cases were registered against those who used children below 14 years of age as workers, the sources added.

It's also unfortunate that there are no proper data on number of child labourers in the city. Earlier available data on number of child labourers in the city are not proper. A proper enumeration of available child labourers is a must. The use of children for domestic work is one of the most disturbing factors in the Indian society. It is disturbing because these children are isolated and separated from their family. Many children in domestic work don't receive their pay. Most of the domestic child workers work between 8 and 18 hours a day. 
They grow up in an environment without parental affection. These children have no or very little freedom and opportunity for recreation and social interaction. The majority of these children are illiterate or barely literate and sometimes they are beaten up.

"If a child below 14 years of age is used as labourer or worker by some person, this act should be regarded as non-cognizable offence. To stop this menace, people should be made aware of the problem," International Labour Organization.

The Labour department faces problems while rescuing such children due to non-availability of executive magistrates at the time of rescue operation. "During such rescue missions, owners sometimes furnish false age certificates of these children working in their garages, hotels, etc.

The National Domestic Workers Movement, in a statement, said, "As there are no specific laws to regulate domestic work, children used as domestic workers live in a condition close to that of slavery. As domestic workers are not recognized as workers and domestic work is not considered as hazardous work, the laws related to children failed to include domestic child workers in the list of child labour."

Suggestion

1. Moreover their problem is not well understood and not protected by the community and the police, Intervention areas that should be stressed are providing free and appropriate education;

2. Improving access to existing health care facilities;

3. Providing appropriate health education

4. Providing family planning service to parents heightening the children right awareness of parent, child and public;

5. And most importantly, providing family support to alleviate poverty

\section{Conclusion}

In conclusion the present study indicated that Child labour could not get the benefit of education as most of the participants are out of school; their health, growth and development are threatened; they have lost the love and affection, care and protection of family because they do not visit their families and cannot enjoy rest and recreation because they work on weekend and holidays.

\section{References}

[1]. Basu Mallik (2006) A study report on knowledge attitude practice on child domestic work with ICDS functionaries, Right Track, Kolkata.

[2]. Child Labour in Shillong, Impulse NGO Network Shillong Meghalaya 2004

[3]. Desai, Kiran and Raj, Nikhil 2001, Child labour in the homebased industries in the wake of legislation: the case of Diamond industry of Surat, Centre for social Studies Surat.

[4]. Lakshmi Rani,D and Roy, Manabendra Nath, (2005) Child domestic work : a violation of human right: quantitative analysis of the situation in West Bengal, Sava the children, New Delhi.

[5]. Mohan Jitendra, et al,(1998) Drug abuse among child workers : an exploratory survey, Department of Psychology, Punjab University, Chandigarh

[6]. Sekar,Helan R (2007) Impact of technological change on the demand for child labour in brassware industry of Muradabad, V.V Giri National Labour institute, NOIDA 